\title{
Preparing and Analyzing Expressed Sequence Tags (ESTs) Library for the Mammary Tissue of Local Turkish Kivircik Sheep
}

\author{
Nehir Ozdemir Ozgenturk, ${ }^{1}$ Zehra Omeroglu Ulu, ${ }^{1}$ Salih Ulu, ${ }^{1}$ Cemal Un, \\ Kemal Ozdem Oztabak, ${ }^{3}$ and Kemal Altunatmaz ${ }^{4}$ \\ ${ }^{1}$ Faculty of Art and Science, Molecular Biology and Genetics, Yıldiz Technical University, Istanbul, Turkey \\ ${ }^{2}$ Department of Biology, Faculty of Art and Science, Ege University, Izmir, Turkey \\ ${ }^{3}$ Department of Biochemistry, Faculty of Veterinary Medicine, Istanbul University, Istanbul, Turkey \\ ${ }^{4}$ Department of Surgery, Faculty of Veterinary Medicine, Istanbul University, Istanbul, Turkey
}

Correspondence should be addressed to Nehir Ozdemir Ozgenturk; nehirozdemir@yahoo.com

Received 18 October 2016; Accepted 7 December 2016; Published 23 January 2017

Academic Editor: Ferenc Olasz

Copyright (C) 2017 Nehir Ozdemir Ozgenturk et al. This is an open access article distributed under the Creative Commons Attribution License, which permits unrestricted use, distribution, and reproduction in any medium, provided the original work is properly cited.

\begin{abstract}
Kivircik sheep is an important local Turkish sheep according to its meat quality and milk productivity. The aim of this study was to analyze gene expression profiles of both prenatal and postnatal stages for the Kivircik sheep. Therefore, two different cDNA libraries, which were taken from the same Kivircik sheep mammary gland tissue at prenatal and postnatal stages, were constructed. Total 3072 colonies which were randomly selected from the two libraries were sequenced for developing a sheep ESTs collection. We used Phred/Phrap computer programs for analysis of the raw EST and readable EST sequences were assembled with the CAP3 software. Putative functions of all unique sequences and statistical analysis were determined by Geneious software. Total 422 ESTs have over $80 \%$ similarity to known sequences of other organisms in NCBI classified by Panther database for the Gene Ontology (GO) category. By comparing gene expression profiles, we observed some putative genes that may be relative to reproductive performance or play important roles in milk synthesis and secretion. A total of 2414 ESTs have been deposited to the NCBI GenBank database (GW996847-GW999260). EST data in this study have provided a new source of information to functional genome studies of sheep.
\end{abstract}

\section{Introduction}

Turkey is an important country in sheep husbandry and there are 33.2 million sheep in the country [1]. Kivircik sheep spread to the Thrace region, Marmara region, and the North Aegean region. They are fed for quality meat, milk, and wool. They are adapted to adverse environmental conditions and resistant parasites. Birth and adult body weight and daily weight gain are $3.7-4 \mathrm{~kg}, 50-70 \mathrm{~kg}$, and $263 \mathrm{~g}$, respectively. In addition, lactation period is 180 days, lactation milk yield is $83 \mathrm{~kg}$, and wool production yield is $1.5 \mathrm{~kg}$ [2].

Colostrum is the first lacteal secretion from the mammary tissue of the mammals after birth [3]. Compared to normal milk, colostrum is clearly richer in contents of immunoglobulin, growth factors, protein, nonprotein nitrogen, fat, ash, minerals, and vitamins [4]. Chemical composition and immunoglobulin level particularly in colostrums exhibits a change within the first $24 \mathrm{~h}$ after birth [5-7]. It is only secreted during the first 72 hours of lactation [8] and the excretion is intense at the first 12-36 hours [7]. Sufficient colostrums intake of newborn lambs in the first days of their lives plays essential role in their healthy growth and reaching to ideal market weight [9]. The raisers are desired to breed very productive animal, so colostrums secretion is a crucially important stage for breeding. Because the compounds of colostrums are important, the genes which are related to colostrums secretion have been the center of interest.

A cDNA library containing the information from the mRNA of a particular tissue or organism is an efficient tool for research on gene structure, function, and manipulation [10]. The production of Expressed Sequence Tags (ESTs) begins with the construction of cDNA libraries. The first description 


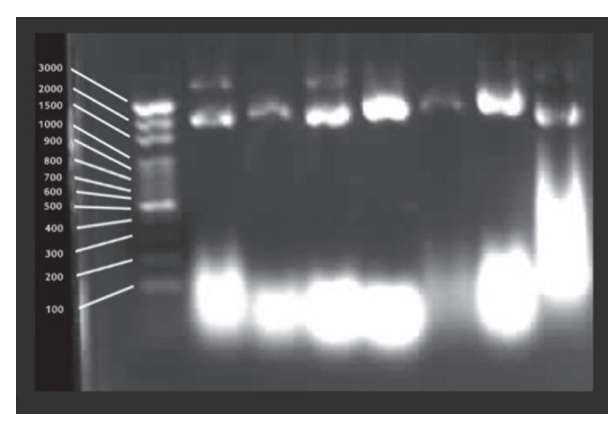

(a)

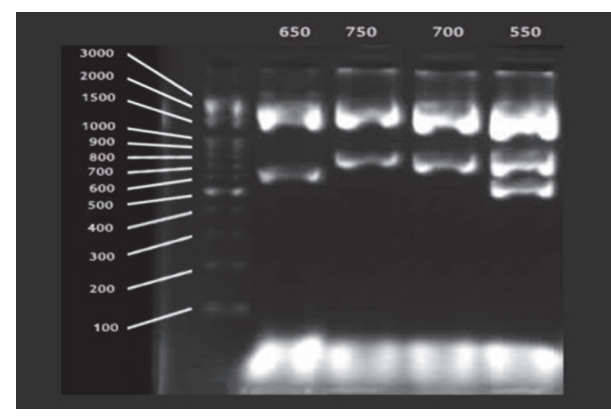

(b)

Figure 1: (a) Prenatal cDNA clones obtaining with alkaline lysis method. (b) Cutting of prenatal cDNA clones with Bsp1407I restriction enzyme.

of EST was reported from humans in 1991 [11]. ESTs, which are obtained in the results of sequencing of cDNA clones, are very important data for genomics studies [12].

In our study, we used one of the native breeds known as Kivircik sheep in Turkey. First of all, mammary tissues of Kivircik sheep were collected in two stages, before parturition and after parturition (the secretion of colostrums known to be considerably high), and two different cDNA libraries were constructed from those tissues. By using the bioinformatic tools, the ESTs were analyzed. Finally, obtained ESTs were compared with other genes of distinct organisms found in databases and putative functions of the genes were estimated. We aimed in this study to obtain mammary gland of gene expression profile at prenatal and postnatal stages and to compare the genetic components of colostrums secretion according to these two stages in Kivircik sheep.

\section{Materials and Methods}

2.1. Tissue Material. Kivircik sheep (Ovis aries) in farm of the Faculty of Veterinary Science at University of Istanbul was used in this study. The mammary tissues from the same sheep were taken by biopsy in 6-8 h during high period of the colostrums secretion after parturition and one week before parturition.

2.2. cDNA Library Construction, Quality Controls, and Sequencing. Total RNA was isolated from $0,377 \mathrm{gr}$ prenatal stage and 1,316 gr postnatal stage mammary tissues with the RNeasy Kit (Qiagen). mRNA was made pure from total RNA using the Oligotex Spin-Column Protocol (Oligotex mRNA Mini Kit, Qiagen, Valencia, CA). Two different cDNA libraries for pre- and postnatal stage tissue were established with $0,23 \mu \mathrm{g}$ and $0,75 \mu \mathrm{g} \mathrm{mRNA}$, respectively. cDNA libraries were constructed with the CloneMiner cDNA Library Construction Kit according to the manufacturer's instructions (Invitrogen, Carlsbad, CA, USA). Double-stranded cDNA was cloned into pDONR222 vector and transformed into E. coli strain DH5 (Invitrogen, Carlsbad, CA, USA). Each cDNA library was plated onto LB-kanamycin agar medium and individual grown colonies were picked into 384-well plates with $\mathrm{SOB}$ medium and inoculated overnight. After the addition of glycerol $(10 \% \mathrm{v} / \mathrm{v})$, the library was stored at $-80^{\circ} \mathrm{C}$.

Plasmid DNA was isolated from casually selected 142 clones with alkaline lysis method [13]. Isolated DNA was digested with Bgl1701 and analyzed by $1 \%$ agarose gel electrophoresis for identifying insert size.

As a template, randomly selected 3072 clones were used for PCR amplification of the cloned cDNA by M13 universal primers. Automated sequencing was performed on an automated high-throughput pipeline using the ABI 3730 capillary sequencer (PE Applied Biosystems, Foster City, CA) at the Genome Sequencing Center, Washington University in St. Louis (WUSTL).

2.3. Sequence Analysis. For analysis of the raw EST data, the low-quality, adapter, and the vector sequences were removed with Phred software [14, 15] (CodonCode Corp., Dedham, MA). The remaining EST sequences were reprocessed by using "cross-match" program which is application of Phrap for the vector sequence trimming $[14,15]$.

Prenatal and postnatal period EST sequences were assembled separately into contigs with Contig Assembly Program 3 (CAP3) [16, 17]. The default values were used for all the parameters. Results were evaluated by using BEAP program which was developed for editing and representing of alignment [18]. Putative functions of all unique sequences and contigs were designated by gene homology based on BLAST [19]. For Blastn and statistical analysis of all the EST sequences, Geneious software was used [20]. ESTs that showed high similarity in GenBank were classified according to molecular function, biological process, cellular component, protein class, and pathway, respectively, based on Panther classification [21].

\section{Results}

3.1. Characterization of cDNA Libraries. Two different cDNA libraries were constructed at prenatal and postnatal stages from mammary gland tissue. In cDNA library for the prenatal period, there occurred $3.6 \times 10^{3}$ clones and its average insert length was $1 \mathrm{~kb}$ (min $200 \mathrm{bp}$ to $1500 \mathrm{bp}$ ) (Figure 1). On the other hand, cDNA library for postnatal stage, which 


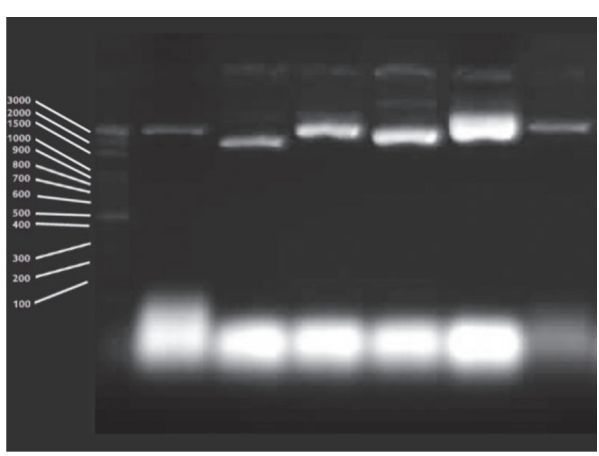

(a)

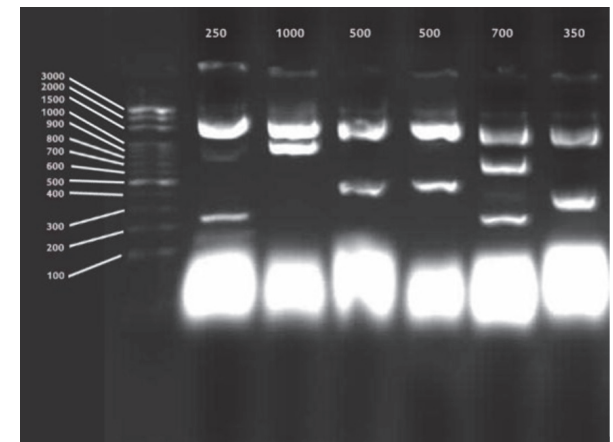

(b)

Figure 2: (a) Postnatal cDNA clones obtaining with alkaline lysis method. (b) Cutting of postnatal cDNA clones with Bsp1407I restriction enzyme.

TABLE 1: The results of analyzing ESTs with Phred software and Geneious software.

\begin{tabular}{lcc}
\hline & Prenatal period & Postnatal period \\
\hline EST number & 1536 & 1536 \\
Low quality EST number & 318 & 340 \\
Quality EST number & 1218 & 1196 \\
Average of ESTs (bp) & 1023 & 1026 \\
The shortest EST (bp) & 542 & 605 \\
The longest EST (bp) & 1587 & 1535 \\
\hline
\end{tabular}

consisted of $4.3 \times 10^{3}$ clones, has an average insert length of $0.9 \mathrm{~kb}$ ranging from 200 to $1500 \mathrm{~kb}$ (Figure 2). After construction of cDNA libraries, 1536 clones were randomly selected and sequenced from prenatal stage library; 1536 clones were randomly selected and sequenced from postnatal stage library. Therefore, 3072 EST sequences were generated.

3.2. BLAST Analysis of ESTs. From obtained 3072 EST sequences, raw EST data were processed and base-called with Phred-Cross_match computer program. The EST sequences were trimmed and vector, adapter, and low-quality bases removed. While 318 low-quality sequences were determined in prenatal cDNA library, 340 low-quality sequences were removed in cDNA library which was constructed at postnatal stage (Table 1). The remaining 1218 high-quality prenatal EST sequences and 1196 high-quality postnatal EST sequences were achieved. Putative functions of all unique sequences were designated by gene homology based on BLAST. Blastn analysis was done using Geneious software. Obtained data was evaluated statistically by this program.

According to these results, length of prenatal ESTs changes between $542 \mathrm{bp}$ and $1587 \mathrm{bp}$; the shortest postnatal EST and the longest postnatal EST were $605 \mathrm{bp}$ and $1535 \mathrm{bp}$, respectively (Table 1 and Figures 3 and 4).

Pursuant to Blastn results of 1218 prenatal ESTs, 154 of them $(12.7 \%)$ which showed $\geq 80$ similarity or $e$ value $\leq$ $1 e-10$ to known sequences of other organisms in NCBI were determined. Also the 1001 ESTs (82.3\%) showed significant similarities to putative genes with score of below $80 \%$ homology and 63 ESTs had no similarity to situated sequences in databases.

Among the 1196 postnatal ESTs, 268 of them (22.4\%) showed $80 \%$ and higher similarity; 923 ESTs (77.2\%) showed similarities with score of $<80$ bits. Also 38 ESTs did not match any registrated sequences in NCBI.

All 2414 EST sequences were submitted to GenBank. ESTs were registered to NCBI under the accession numbers of GW996847 to GW999260.

3.3. GO Analysis of ESTs. Total 422 ESTs which show $80 \%$ and over $80 \%$ similarity to known sequences of other organisms in NCBI were classified according to GO terms such as molecular function, biological process, cellular components, protein class, and pathway with PANTHER database (Figures 5 and 6). 154 and 268 ESTs of these total ESTs were prenatal and postnatal ESTs, respectively. According to the statistical results of PANTHER of high similarity prenatal and postnatal ESTs, 137 and 127 different putative genes were listed and classified, respectively, by GO terms. 39 prenatal ESTs and 37 postnatal EST were uncategorized.

9 different types of molecular functions were found in prenatal ESTs. The common molecular function GO terms are "binding" which consists of 43 proteins and "catalytic activity" which consists of 27 proteins. Moreover, most of the postnatal ESTs in the molecular function GO term were assigned the same categories, "binding" and "catalytic activity." In the biological process category that recognizes series of events or molecular functions, 56 and 30 of prenatal ESTs and 55 and 20 of postnatal ESTs were viewed in "metabolic process" and "cellular process," respectively. The cellular component GO identifies locations at the levels of subcellular structures and macromolecular complexes. In this GO term category, the prenatal ESTs were accumulated more than postnatal ESTs in "cell part," "macromolecular complex," and "organelle." According to protein class GO term classification of Panther database, 23 of prenatal ESTs and 20 of postnatal ESTs most observed "nucleic acid binding" category. On 


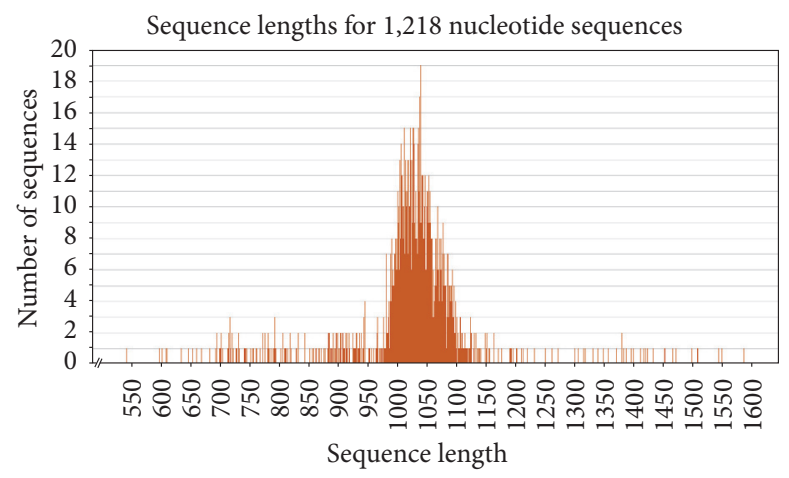

Figure 3: The length of prenatal ESTs.

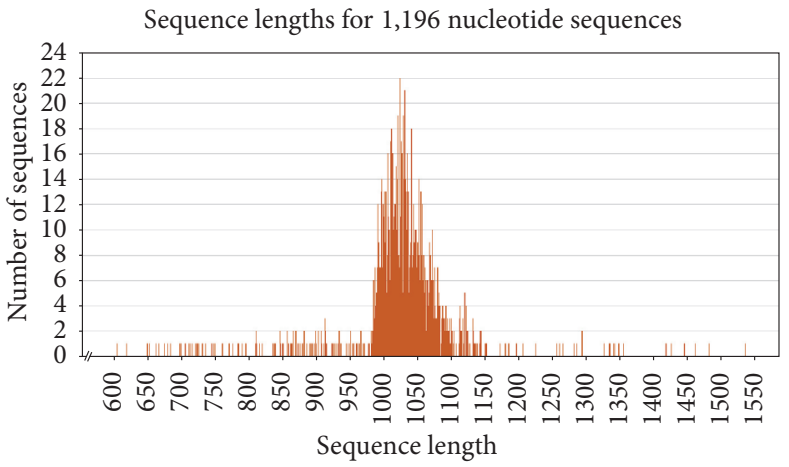

Figure 4: The length of postnatal ESTs.

the other hand, Panther database gives information about pathway GO term. When we analyzed prenatal and postnatal ESTs, "B cell activation," "T cell activation," and "Huntington disease" categories included some prenatal proteins; moreover, "apoptosis signaling pathway," "p53 pathway," and "Parkinson disease" categories contained some postnatal proteins.

3.4. Analyzing of Contigs. 1218 high-quality prenatal EST sequences and 1196 high-quality postnatal EST sequences were appointed to achieve contig. Fragment assembly was done with the CAP3 software. According to CAP3 result the prenatal stage EST sequences into 23 contigs and postnatal stage EST sequences into 27 contigs were assembled. Furthermore, in prenatal stage contigs, the longest contig is $1394 \mathrm{bp}$, it is 2068 in postnatal stage contig. The number of singlets is 1164 and 1059, respectively (Table 2).

The results which were obtained by CAP3 software were evaluated with the program BEAP which was developed for editing and representing of alignment (Figure 7).

All of the contigs were designated by Blastn in NCBI. The Blastn results of prenatal and postnatal contigs are shown in Tables 3 and 4 , respectively.

Among the Blastn results of prenatal contigs, 7 of them showed high similarities. These are a unique protein associated with intracellular transfer of membrane by coated vesicles "clathrin," protein that plays role in protein synthesis, "elongation factor-1," a member of the mitochondrial carrier family, "alpha solute carrier family, member 13,"
TABLE 2: The analysis of prenatal and postnatal contigs by CAP3.

\begin{tabular}{lcc}
\hline & Prenatal period & Postnatal period \\
\hline Contig number & 23 & 27 \\
Singlet number & 1164 & 1059 \\
The longest contig (bp) & 1394 & 2068 \\
The shortest contig (bp) & 765 & 994 \\
\hline
\end{tabular}

protein that related with immune system, "immunoglobulin gamma one chain," a gene that encodes the glycodelin protein, "progestagen-associated endometrial protein (PAEP)," a major component of a specific type of lipoprotein called very low-density lipoproteins (VLDLs), and "apolipoprotein E." Additionally, 10 of 23 prenatal contigs showed similarities to putative different ribosomal proteins in NCBI with score of $<80$ (Table 3 ).

As shown in Table 4, 11 of 27 postnatal contigs have similarities with score of $\geq 80$ bits or $e$ value $\leq 10^{-10}$ according to Blastn. 3 postnatal contigs of high similarity postnatal contigs include 3 different ribosomal proteins. In addition, 5 postnatal contigs interacte with calcium and calcium phosphate and self-aggregate to be organized into a supramolecular structure "alpha casein S1 and S2." The other two contigs show high similarities to putative proteins which are "sperm associated antigen 8 (SPAG8)" and "translation elongation factor 1 alpha." Important putative genes of the postnatal contigs which showed resemblance below 79\% in NCBI are "collagen 

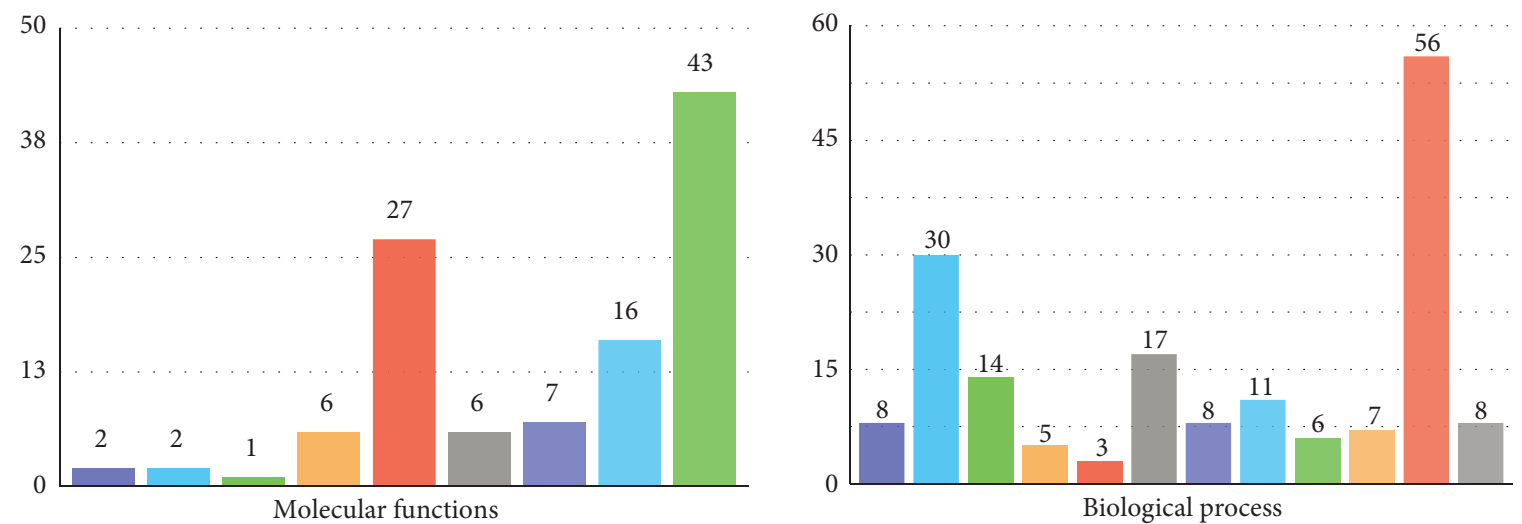

- Transporter activity (GO:0005215)

- Translation regulator activity (GO:0045182)

- Protein binding transcription factor activity (GO:0000988)

Enzyme regulator activity (GO:0030234)

- Catalytic activity (GO:0003824)

- Receptor activity (GO:0004872)

nucleic acid binding transcription factor activity (GO:0001071)

- Structural molecule activity (GO:0005198)

- Binding (GO:0005488)

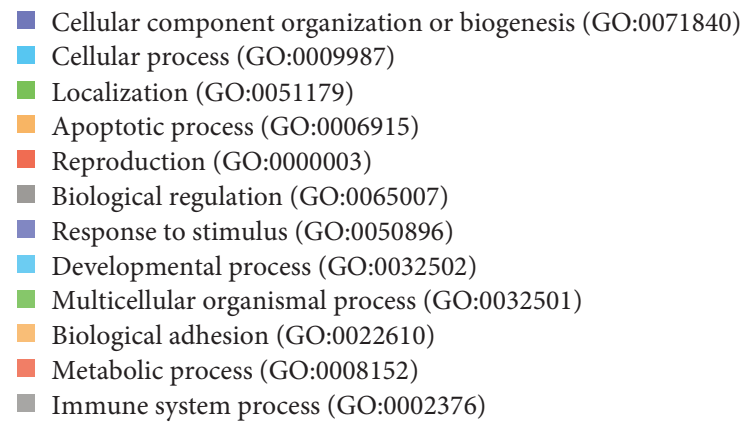

(a)

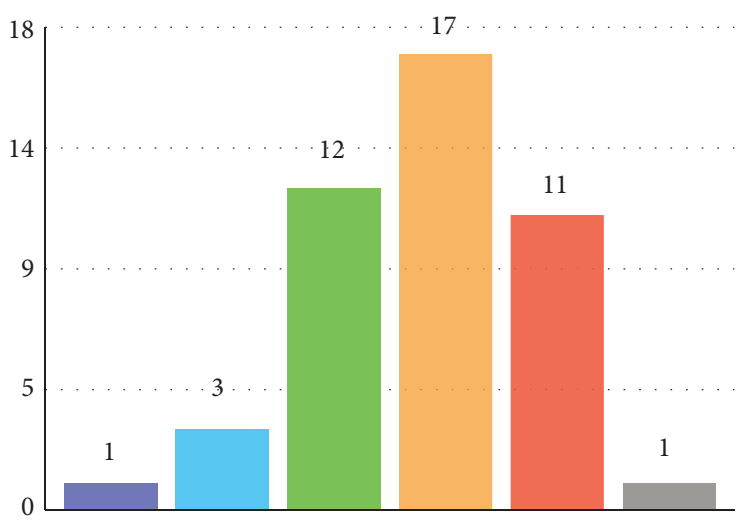

Cellular component

Cell junction (GO:0030054)

Membrane (GO:0016020)

- Macromolecular complex (GO:0032991)

- Cell part (GO:0044464)

- Organelle (GO:0043226)

- Extracellular region (GO:0005576)

(c)

(b)

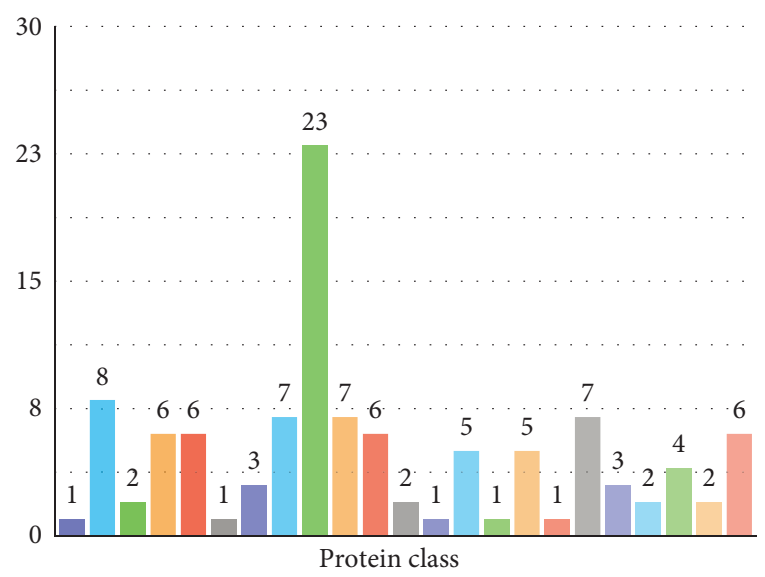

Protease (PC00190)

- Cytoskeletal protein (PC00085)

- Transporter (PC00227)

Transferase (PC00220)

- Oxidoreductase (PC00176)

- Lyase (PC00144)

- Cell adhesion molecule (PC00069)

Ligase (PC00142)

- Nucleic acid binding (PC00171)

- Signaling molecule (PC00207)

- Enzyme modulator (PC00095)

- Calcium-binding protein (PC00060)

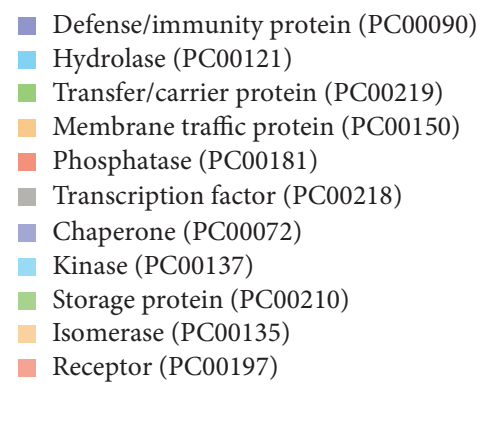

(d)

FIGURE 5: GO terms distribution in the molecular function (a), the biological process (b), the cellular components (c), and the protein class (d) for prenatal ESTs. 


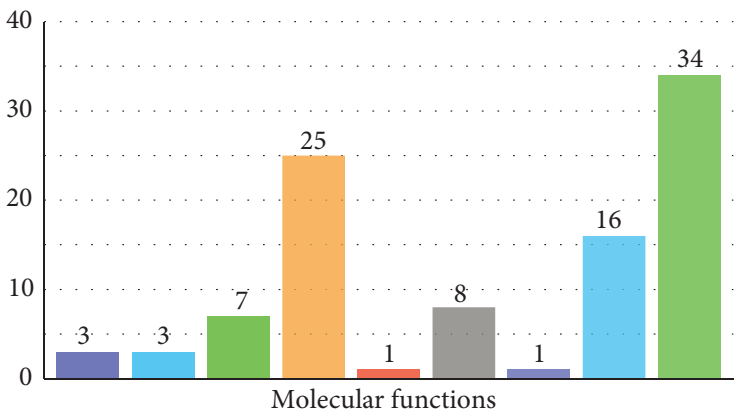

- Transporter activity (GO:0005215)

- Translation regulator activity (GO:0045182)

- Enzyme regulator activity (GO:0030234)

Catalytic activity (GO:0003824)

- Receptor activity (GO:0004872)

nucleic acid binding transcription factor activity (GO:0001071)

- Antioxidant activity (GO:0016209)

- Structural molecule activity (GO:0005198)

- Binding (GO:0005488)

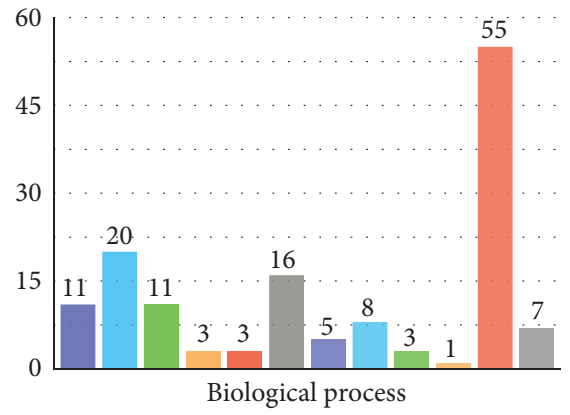

Cellular component organization or biogenesis (GO:0071840)

Cellular process (GO:0009987)

- Localization (GO:0051179)

- Apoptotic process (GO:0006915)

- Reproduction (GO:0000003)

- Biological regulation (GO:0065007)

- Response to stimulus (GO:0050896)

- Developmental process (GO:0032502)

- Multicellular organismal process (GO:0032501)

- Biological adhesion (GO:0022610)

- Metabolic process (GO:0008152)

- Immune system process (GO:0002376) (a)

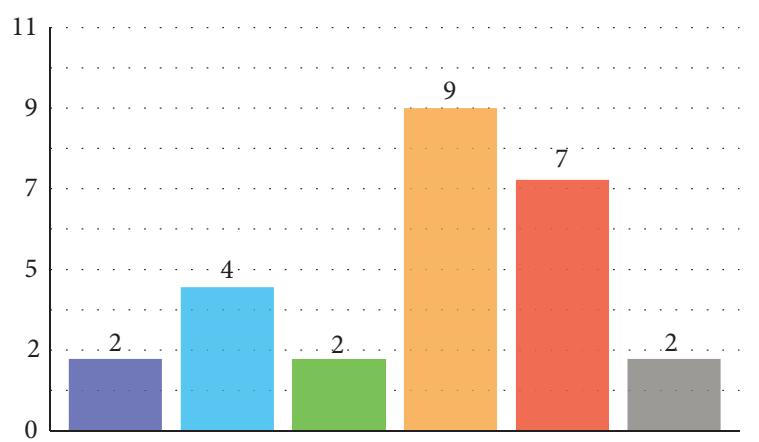

Cellular component (b)

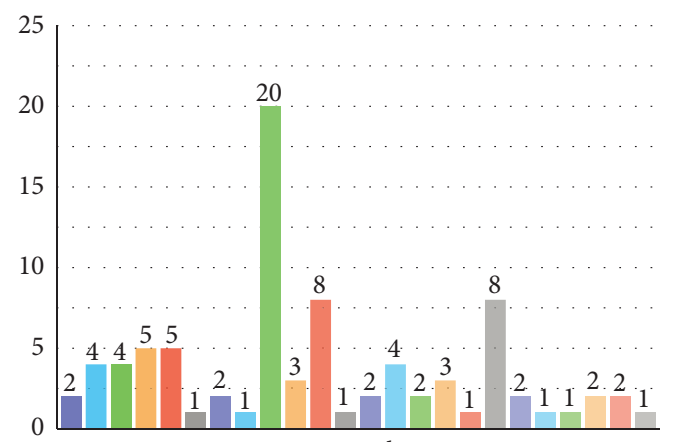

Protein class
Membrane (GO:0016020)

- Macromolecular complex (GO:0032991)

Extracellular matrix (GO:0031012)

- Cell part (GO:0044464)

Organelle (GO:0043226)

Extracellular region (GO:0005576)

\footnotetext{
Extracellular matrix protein (PC00102) — Defense/immunity protein (PC00090)

- Cytoskeletal protein (PC00085)

- Transporter (PC00227)

- Transferase (PC00220)

- Oxidoreductase (PC00176)

- Lyase (PC00144)

- Cell adhesion molecule (PC00069)

Ligase (PC00142)

- Nucleic acid binding (PC00171)

- Signaling molecule (PC00207)

- Enzyme modulator (PC00095)

- Calcium-binding protein (PC00060)

\author{
- Hydrolase (PC00121) \\ - Transfer/carrier protein (PC00219) \\ - Membrane traffic protein (PC00150) \\ - Phosphatase (PC00181) \\ - Transcription factor (PC00218) \\ - Structural protein (PC00211) \\ - Kinase (PC00137) \\ - Storage protein (PC00210) \\ - Isomerase (PC00135) \\ - Receptor (PC00197)
}

- Chaperone (PC00072)
}

(c)

(d)

FiguRE 6: GO terms distribution in the molecular function (a), the biological process (b), the cellular components (c), and the protein class (d) for postnatal ESTs. 
TABLE 3: The Blastn results of prenatal contigs.

\begin{tabular}{|c|c|c|c|c|c|}
\hline Contig number & Description & Query coverage & Max. ident. & Length of contig (bp) & $\begin{array}{c}\text { The number of ESTs } \\
\text { in the contig }\end{array}$ \\
\hline Contig 1 & $\begin{array}{l}\text { Bos taurus cDNA clone } \\
\text { IMAGE: } 7944277\end{array}$ & $56 \%$ & $92 \%$ & 768 & 4 \\
\hline Contig 2 & $\begin{array}{l}\text { Bos taurus ribosomal } \\
\text { protein S25, mRNA } \\
\text { (cDNA clone MGC: } \\
\text { 127761, IMAGE: } \\
\text { 7962930), complete cds }\end{array}$ & $45 \%$ & $92 \%$ & 1121 & 2 \\
\hline Contig 3 & $\begin{array}{l}\text { Homo sapiens BAC clone } \\
\text { RP11-67M24 from } 4 \\
\text { complete sequence }\end{array}$ & $59 \%$ & $72 \%$ & 1049 & 2 \\
\hline Contig 4 & $\begin{array}{l}\text { Bos taurus thymosin } \\
\text { beta 4, X-linked, mRNA } \\
\text { (cDNA clone MGC: } \\
\text { 157367, IMAGE: } \\
\text { 8260878), complete cds }\end{array}$ & $73 \%$ & $94 \%$ & 860 & 2 \\
\hline Contig 5 & $\begin{array}{l}\text { Equus caballus clathrin, } \\
\text { light chain (Lca) } \\
\text { (CLTA), mRNA > } \\
\text { dbj|AB495091.1| Equus } \\
\text { caballus clc mRNA for } \\
\text { clathrin light chain, } \\
\text { complete cds }\end{array}$ & $85 \%$ & $96 \%$ & 1193 & 2 \\
\hline Contig 6 & $\begin{array}{l}\text { PREDICTED: Ovis aries } \\
\text { elongation factor-1 alpha } \\
\text { (LOC100125610), mRNA }\end{array}$ & $83 \%$ & $98 \%$ & 1083 & 5 \\
\hline Contig 7 & $\begin{array}{c}\text { Ovis aries ribosomal } \\
\text { protein S19 (RPS19), } \\
\text { mRNA }\end{array}$ & $47 \%$ & $98 \%$ & 1171 & 4 \\
\hline Contig 8 & $\begin{array}{l}\text { PREDICTED: Ovis aries } \\
\text { solute carrier family } 25 \\
\text { (aspartate/glutamate } \\
\text { carrier), member } 13 \\
\text { (SLC25A13), mRNA }\end{array}$ & $80 \%$ & $96 \%$ & 1049 & 2 \\
\hline Contig 9 & $\begin{array}{l}\text { O. aries } \mathrm{mRNA} \text { for } \\
\text { immunoglobulin } \\
\text { gamma-1 chain secreted } \\
\text { form }\end{array}$ & $88 \%$ & $87 \%$ & 1394 & 2 \\
\hline Contig 10 & $\begin{array}{l}\text { PREDICTED: } \\
\text { Pantholops hodgsonii 60S } \\
\text { ribosomal protein } \\
\text { L32-like } \\
\text { (LOC102314866), mRNA }\end{array}$ & $62 \%$ & $93 \%$ & 842 & 2 \\
\hline Contig 11 & $\begin{array}{l}\text { Bos taurus ribosomal } \\
\text { protein L31 (RPL31), } \\
\text { mRNA > gb|BC102125.1| } \\
\text { Bos taurus ribosomal } \\
\text { protein L31, mRNA } \\
\text { (cDNA clone MGC: } \\
\text { 127011, IMAGE: } \\
\text { 7942112), complete cds }\end{array}$ & $47 \%$ & $92 \%$ & 1088 & 2 \\
\hline
\end{tabular}


TABle 3: Continued.

\begin{tabular}{|c|c|c|c|c|c|}
\hline Contig number & Description & Query coverage & Max. ident. & Length of contig (bp) & $\begin{array}{c}\text { The number of ESTs } \\
\text { in the contig }\end{array}$ \\
\hline Contig 12 & $\begin{array}{c}\text { Bos taurus ribosomal } \\
\text { protein L13a (RPL13A), } \\
\text { mRNA > gb|BC103039.1 } \\
\text { Bos taurus ribosomal } \\
\text { protein L13a, mRNA } \\
\text { (cDNA clone MGC: } \\
\text { 128198, IMAGE: } \\
\text { 7984430), complete } \\
\text { cds }\end{array}$ & $54 \%$ & $95 \%$ & 1239 & 2 \\
\hline Contig 13 & $\begin{array}{l}\text { Bos taurus ribosomal } \\
\text { protein S7 (RPS7), } \\
\text { mRNA > gb|BC146133.1| } \\
\text { Bos taurus ribosomal } \\
\text { protein S7, mRNA } \\
\text { (cDNA clone MGC: } \\
\text { 165697, IMAGE: } \\
\text { 8068046), complete cds }\end{array}$ & $68 \%$ & $93 \%$ & 1036 & 2 \\
\hline Contig 14 & $\begin{array}{c}\text { Capra hircus serum } \\
\text { amyloid A3 } \\
\text { (LOC100860781), mRNA }\end{array}$ & $67 \%$ & $92 \%$ & 875 & 4 \\
\hline Contig 15 & $\begin{array}{c}\text { Capra hircus ribosomal } \\
\text { protein S18 (RPS18) } \\
\text { mRNA, complete } \\
\text { cds }\end{array}$ & $73 \%$ & $95 \%$ & 765 & 3 \\
\hline Contig 16 & $\begin{array}{c}\text { Bos taurus } \\
\text { progestagen-associated } \\
\text { endometrial protein } \\
\text { (PAEP), mRNA }\end{array}$ & $84 \%$ & $92 \%$ & 1032 & 4 \\
\hline Contig 17 & $\begin{array}{c}\text { PREDICTED: Ovis aries } \\
\text { ribosomal protein S11 } \\
\text { (LOC100037666), } \\
\text { mRNA }\end{array}$ & $49 \%$ & $94 \%$ & 1101 & 2 \\
\hline Contig 18 & $\begin{array}{c}\text { Capra hircus ribosomal } \\
\text { protein S18 (RPS18) } \\
\text { mRNA, complete } \\
\text { cds }\end{array}$ & $40 \%$ & $97 \%$ & 1297 & 2 \\
\hline Contig 19 & $\begin{array}{c}\text { Bos taurus endothelial } \\
\text { differentiation-related } \\
\text { factor } 1 \text { (EDF1), mRNA } \\
\text { > gb|BC102246.1| Bos } \\
\text { taurus endothelial } \\
\text { differentiation-related } \\
\text { factor 1, mRNA (cDNA } \\
\text { clone MGC: 127033, } \\
\text { IMAGE: 7942128), } \\
\text { complete cds }\end{array}$ & $74 \%$ & $88 \%$ & 1082 & 2 \\
\hline Contig 20 & $\begin{array}{l}\text { PREDICTED: Bubalus } \\
\text { bubalis uncharacterized } \\
\text { LOC102396380 } \\
\text { (LOC102396380), } \\
\text { misc_RNA }\end{array}$ & $64 \%$ & $83 \%$ & 890 & 2 \\
\hline
\end{tabular}


TABLE 3: Continued.

\begin{tabular}{|c|c|c|c|c|c|}
\hline Contig number & Description & Query coverage & Max. ident. & Length of contig (bp) & $\begin{array}{l}\text { The number of ESTs } \\
\text { in the contig }\end{array}$ \\
\hline Contig 21 & $\begin{array}{l}\text { Bos taurus ribosomal } \\
\text { protein L11 (RPL11), } \\
\text { mRNA > gb|BC102524.1| } \\
\text { Bos taurus ribosomal } \\
\text { protein L11, mRNA } \\
\text { (cDNA clone MGC: } \\
\text { 127967, IMAGE: } \\
\text { 7956291), complete cds }\end{array}$ & $63 \%$ & $95 \%$ & 965 & 2 \\
\hline Contig 22 & $\begin{array}{c}\text { Bos taurus ribosomal } \\
\text { protein L7a (RPL7A), } \\
\text { mRNA }\end{array}$ & $46 \%$ & $87 \%$ & 1097 & 2 \\
\hline Contig 23 & $\begin{array}{c}\text { Bos taurus } \\
\text { apolipoprotein E, mRNA } \\
\text { (cDNA clone MGC: } \\
\text { 127905, IMAGE: } \\
\text { 7962554), complete cds }\end{array}$ & $87 \%$ & $90 \%$ & 1288 & 3 \\
\hline
\end{tabular}

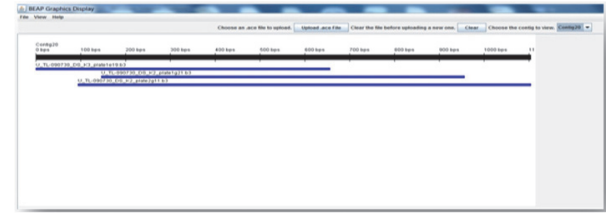

Figure 7: The result of Contig 20 that was obtained by CAP3 with BEAP.

type III alpha 1," "nuclear protein, transcriptional regulator," "beta-2-microglobulin," "thymosin beta 4," "beta-casein," and different ribosomal proteins.

\section{Discussion}

EST projects are powerful tools for analyzing gene expression patterns in a given tissue and/or at a certain stage and the identification of genes [22-24]. These technologies are very important for obtaining genomic sequence information of organisms [25]. In the molecular studies, generation of ESTs is a perfect and unique approach because it allows both expression and estimation and discovery of new genes to be conducted at the same time. Consequently, analysis of expression of a large number of gene profile supplies for scientists to find their functions and facilitates the understanding activity of biological processes in specific tissue or cell of organisms at the certain stage [26].

In this study, we obtained two different EST libraries from Kivircik sheep mammary gland at one week before parturition and $6-8 \mathrm{~h}$ after parturition. Because colostrums are only secreted during the first 72 hours after parturition [8], we aimed in this project to achieve putative gene profiling at different time and find the genetic components of colostrums secretion in Kivircik sheep.

The results of the analyzing contig and GO analysis of ESTs and the Blastn analysis of the ESTs showed $80 \%$ and higher similarity to putative genes in NCBI. Moreover, we have determined gene expression profile of mammary gland at the different developmental stages, which are prenatal and postnatal.

Table 5 shows Blastn results of some breed-specific expressed genes in all ESTs of prenatal and postnatal ESTs. According to these results, levels of ribosomal protein, transcription factors, and translation factors were found about the same level at both stages. CREB2F, SRF, AKNA, CRTC2, TCF20, and SPDEF transcription factors were observed in prenatal ESTs and also ELF5, NUPR1, BTAF1, TCF12, TFE3, and TCF20 transcription factors were observed in postnatal ESTs. Due to the high level of protein synthesis in the lactation phase, expression of the proteins that participate in ribosomal structure increases at the preparation lactation stage. Also, the genes that have function in transcriptional and translational regulation are expressed highly before parturition [27]. Additionally, we have observed known putative genes related to immune system, growth, and lipid metabolism. These expressed genes which improve quality of milk are "immunoglobulins," "MHC," and "beta-2-microglobulin." Because lactation begins few weeks before parturition [28] and we choose sequenced cDNA clones randomly, these putative genes are found approximately at the same rate in prenatal and postnatal ESTs. Besides, expressions of genes related to milk production are minimal, because the milk is not secreted from mammary gland before the parturition. On the other hand, the milk proteins that affect milk quality are defined as significant milk genes. We have observed their expressions to be high in the lactation stage such as "caseins (alpha-S1, alpha-S2, beta, and kappa casein)" and whey proteins "beta-lactoglobulin" and "alpha-lactalbumin." Expression of the milk proteins was slightly near the end of gestation, which can be used as a symbol of the maturity of mammary epithelial cells [29].

On the other hand, in respect of GO analysis, GO terms were identified and observed on five categories, such as 
TABLE 4: The Blastn results of postnatal contigs.

\begin{tabular}{|c|c|c|c|c|c|}
\hline Contig number & Description & Query coverage & Max. ident. & Length of contig (bp) & $\begin{array}{c}\text { The number of ESTs } \\
\text { in contig }\end{array}$ \\
\hline Contig 1 & $\begin{array}{l}\text { PREDICTED: Capra } \\
\text { hircus sperm } \\
\text { associated antigen } 8 \\
\text { (SPAG8), transcript } \\
\text { variant X3, misc_RNA }\end{array}$ & $87 \%$ & $90 \%$ & 1015 & 2 \\
\hline Contig 2 & $\begin{array}{l}\text { PREDICTED: Capra } \\
\text { hircus collagen type } \\
\text { III alpha } 1 \\
\text { (LOC100860938), } \\
\text { mRNA }\end{array}$ & $67 \%$ & $87 \%$ & 1332 & 2 \\
\hline Contig 3 & $\begin{array}{l}\text { PREDICTED: Capra } \\
\text { hircus nuclear protein, } \\
\text { transcriptional } \\
\text { regulator, } 1 \text { (NUPR1), } \\
\text { mRNA }\end{array}$ & $58 \%$ & $95 \%$ & 1039 & 3 \\
\hline Contig 4 & $\begin{array}{l}\text { Bos taurus eukaryotic } \\
\text { translation elongation } \\
\text { factor } 1 \text { alpha } 1 \text {, } \\
\text { mRNA (cDNA clone } \\
\text { MGC: } 126913 \text {, } \\
\text { IMAGE: } 7928985 \text { ), } \\
\text { complete cds }\end{array}$ & $95 \%$ & $90 \%$ & 1992 & 10 \\
\hline Contig 5 & $\begin{array}{c}\text { Bos taurus ribosomal } \\
\text { protein S3 (RPS3), } \\
\text { mRNA > } \\
\text { gb|BC102090.1| Bos } \\
\text { taurus ribosomal } \\
\text { protein S3, mRNA } \\
\text { (cDNA clone MGC: } \\
\text { 127206, IMAGE: } \\
\text { 7945675), complete } \\
\text { cds }\end{array}$ & $82 \%$ & $92 \%$ & 1074 & 2 \\
\hline Contig 6 & $\begin{array}{l}\text { Solanum lycopersicum } \\
\text { chromosome chl2, } \\
\text { complete genome }\end{array}$ & $30 \%$ & $67 \%$ & 2068 & 2 \\
\hline Contig 7 & $\begin{array}{c}\text { PREDICTED: } \\
\text { Pantholops hodgsonii } \\
\text { GTPase IMAP family } \\
\text { member 5-like } \\
\text { (LOC102329836), } \\
\text { transcript variant X5, } \\
\text { mRNA }\end{array}$ & $17 \%$ & $91 \%$ & 1031 & 2 \\
\hline Contig 8 & $\begin{array}{c}\text { C. hircus mRNA for } \\
\text { asl-casein }\end{array}$ & $83 \%$ & $91 \%$ & 1072 & 3 \\
\hline Contig 9 & $\begin{array}{c}\text { Bos taurus } \\
\text { beta-2-microglobulin } \\
\text { (B2M), mRNA > } \\
\text { gb|BC118352.1| Bos } \\
\text { taurus } \\
\text { beta-2-microglobulin, } \\
\text { mRNA (cDNA clone } \\
\text { MGC: } 140690, \\
\text { IMAGE: } 8275195) \\
\text { complete cds }\end{array}$ & $79 \%$ & $89 \%$ & 1383 & 2 \\
\hline
\end{tabular}


TABle 4: Continued.

\begin{tabular}{|c|c|c|c|c|c|}
\hline Contig number & Description & Query coverage & Max. ident. & Length of contig (bp) & $\begin{array}{c}\text { The number of ESTs } \\
\text { in contig }\end{array}$ \\
\hline Contig 10 & $\begin{array}{c}\text { Ovis aries } \\
\text { alpha-S1-casein } \\
\text { (csn1s1), mRNA > } \\
\text { emb|X03237.1| Sheep } \\
\text { mRNA for } \\
\text { alpha-S1-casein }\end{array}$ & $83 \%$ & $95 \%$ & 1283 & 5 \\
\hline Contig 11 & $\begin{array}{c}\text { Ovis aries } \\
\text { alpha-S2-casein } \\
\text { (LOC443383), mRNA } \\
\text { > emb|X03238.1| } \\
\text { Sheep mRNA for } \\
\text { alpha-S2-casein }\end{array}$ & $85 \%$ & $91 \%$ & 1042 & 4 \\
\hline Contig 12 & $\begin{array}{c}\text { Ovis aries } \\
\text { alpha-S2-casein } \\
\text { (LOC443383), mRNA } \\
\text { > emb|X03238.1| } \\
\text { Sheep mRNA for } \\
\text { alpha-S2-casein }\end{array}$ & $82 \%$ & $95 \%$ & 1071 & 13 \\
\hline Contig 13 & $\begin{array}{l}\text { Ovis aries breed Small } \\
\text { Tail Han Sheep } \\
\text { thymosin beta } 4, \\
\text { X-linked (ThymB4X) } \\
\text { mRNA, complete cds }\end{array}$ & $60 \%$ & $95 \%$ & 1048 & 2 \\
\hline Contig 14 & $\begin{array}{l}\text { Sheep mRNA for } \\
\text { beta-casein }\end{array}$ & $79 \%$ & $90 \%$ & 1487 & 21 \\
\hline Contig 15 & $\begin{array}{c}\text { PREDICTED: Bos } \\
\text { taurus } \\
\text { N-ethylmaleimide- } \\
\text { sensitive factor, } \\
\text { transcript variant } 4 \\
\text { (NSF), mRNA }\end{array}$ & $80 \%$ & $93 \%$ & 1116 & 2 \\
\hline Contig 16 & $\begin{array}{l}\text { Bos taurus ribosomal } \\
\text { protein S4, X-linked } \\
\text { (RPS4X), mRNA > } \\
\text { gb|BC102476.1| Bos } \\
\text { taurus ribosomal } \\
\text { protein S4, Y-linked 2, } \\
\text { mRNA (cDNA clone } \\
\text { MGC: } 127573, \\
\text { IMAGE: } 7950762 \text { ), } \\
\text { complete cds }\end{array}$ & $84 \%$ & $92 \%$ & 1088 & 2 \\
\hline Contig 17 & $\begin{array}{l}\text { Bos taurus ribosomal } \\
\text { protein L27a, mRNA } \\
\text { (cDNA clone MGC: } \\
\text { 133578, IMAGE: } \\
\text { 8058503), complete } \\
\text { cds }\end{array}$ & $38 \%$ & $93 \%$ & 1361 & 2 \\
\hline Contig 18 & $\begin{array}{c}\text { Bovine } \\
\text { alpha-S2-casein type } \\
\text { A protein (CASAS2) } \\
\text { gene, exons 1-18 }\end{array}$ & $66 \%$ & $89 \%$ & 1054 & 2 \\
\hline Contig 19 & $\begin{array}{c}\text { Ovis aries } \\
\text { alpha-S1-casein } \\
\text { (csn1s1), mRNA > } \\
\text { emb|X03237.1| Sheep } \\
\text { mRNA for } \\
\text { alpha-S1-casein }\end{array}$ & $85 \%$ & $93 \%$ & 994 & 2 \\
\hline
\end{tabular}


TABle 4: Continued.

\begin{tabular}{|c|c|c|c|c|c|}
\hline Contig number & Description & Query coverage & Max. ident. & Length of contig (bp) & $\begin{array}{c}\text { The number of ESTs } \\
\text { in contig }\end{array}$ \\
\hline Contig 20 & $\begin{array}{c}\text { Ovis aries casein } \\
\text { kappa }(\mathrm{CSN} 3), \\
\text { mRNA }> \\
\text { emb|X51822.1| Sheep } \\
\text { kappa-Cn mRNA for } \\
\text { kappa-casein }\end{array}$ & $79 \%$ & $95 \%$ & 1105 & 3 \\
\hline Contig 21 & $\begin{array}{l}\text { PREDICTED: Capra } \\
\text { hircus 40S ribosomal } \\
\text { protein S15-like } \\
\text { (LOC102191702), } \\
\text { mRNA }\end{array}$ & $45 \%$ & $96 \%$ & 1060 & 2 \\
\hline Contig 22 & $\begin{array}{l}\text { Ovis aries clone } 7 \\
\text { ribosomal protein SA } \\
\text { (RPSA) pseudogene, } \\
\text { complete sequence }\end{array}$ & $50 \%$ & $97 \%$ & 1318 & 2 \\
\hline Contig 23 & $\begin{array}{c}\text { Bos taurus ribosomal } \\
\text { protein S3A, mRNA } \\
\text { (cDNA clone MGC: } \\
\text { 127088, IMAGE: } \\
\text { 7943245), complete } \\
\text { cds }\end{array}$ & $86 \%$ & $91 \%$ & 1069 & 2 \\
\hline Contig 24 & $\begin{array}{c}\text { PREDICTED: Ovis } \\
\text { aries ribosomal } \\
\text { protein L6 (RPL6), } \\
\text { mRNA }\end{array}$ & $75 \%$ & $90 \%$ & 1150 & 2 \\
\hline Contig 25 & $\begin{array}{c}\text { PREDICTED: } \\
\text { Pantholops hodgsonii } \\
\text { 40S ribosomal protein } \\
\text { S25-like } \\
\text { (LOC102318811), } \\
\text { mRNA }\end{array}$ & $45 \%$ & $96 \%$ & 1079 & 2 \\
\hline Contig 26 & $\begin{array}{c}\text { Bubalus bubalis } \\
\text { alpha-S1-casein } \\
\text { mRNA, complete cds }\end{array}$ & $82 \%$ & $93 \%$ & 1439 & 38 \\
\hline Contig 27 & $\begin{array}{l}\text { Ovis aries cell line } \\
\text { 1LL2 mitochondrion, } \\
\text { complete genome }\end{array}$ & $79 \%$ & $97 \%$ & 1059 & 3 \\
\hline
\end{tabular}

molecular function, biological process, cellular components, protein class, and pathways. Prenatal and postnatal highsimilarity ESTs were classified with Panther database according to GO terms. According to comparison of these results, prenatal and postnatal ESTs were classified almost in the same category.

After our study, using large-scale EST sequencing as strategy, we have constructed Kivircik sheep mammary gland gene expression profiles in different stages and found prelactation and lactation (especially secreting colostrum) specific genes. These results will help us understand the comparison of mammary gland gene expression profiles between two distinct stages and provide new clues for genomic research. Because our ESTs data just only matched the other organisms in NCBI by approximately $50 \%$, it will also provide the increasing number of ESTs of Ovis aries in NCBI Genbank database and new genes about Ovis aries. This work will improve with the research of different developmental stage of mammary gland.

\section{Competing Interests}

The authors declare that there are no competing interests regarding the publication of this paper.

\section{Acknowledgments}

This research has been supported by Yildiz Technical University Scientific Research Projects Coordination Department (Project no. 27-01-07-02). 
TABLE 5: The percentage and number of some expressed genes in prenatal and postnatal ESTs.

\begin{tabular}{|c|c|c|c|c|c|}
\hline \multicolumn{3}{|c|}{ Prenatal ESTs } & \multicolumn{3}{|c|}{ Postnatal ESTs } \\
\hline Genes & EST\% & $\begin{array}{c}\text { Number of } \\
\text { ESTs }\end{array}$ & Genes & EST\% & $\begin{array}{l}\text { Number of } \\
\text { ESTs }\end{array}$ \\
\hline $\begin{array}{l}\text { Casein (alpha-S1, } \\
\text { alpha-S2, beta, kappa) }\end{array}$ & $1,2 \%$ & 15 & $\begin{array}{c}\text { Casein (alpha-S1, } \\
\text { alpha-S2, beta, kappa) }\end{array}$ & $23,1 \%$ & 277 \\
\hline Immunoglobulins & $2,9 \%$ & 36 & Immunoglobulins & $1,4 \%$ & 17 \\
\hline $\mathrm{MHC}$ & $1,6 \%$ & 20 & MHC & $0,4 \%$ & 5 \\
\hline $\begin{array}{l}\text { Translation factors, } \\
\text { elongation factors }\end{array}$ & $2,3 \%$ & 29 & $\begin{array}{l}\text { Translation factors, } \\
\text { elongation factors }\end{array}$ & $2,5 \%$ & 31 \\
\hline $\begin{array}{l}\text { Transcription factors } \\
\text { (CREB2F, SRF, AKNA, } \\
\text { CRTC2, TCF20, SPDEF) }\end{array}$ & $0,4 \%$ & 6 & $\begin{array}{c}\text { Transcription factors } \\
\text { (ELF5, NUPR1, BTAF1, } \\
\text { TCF12, TFE3, TCF2) }\end{array}$ & $0,6 \%$ & 8 \\
\hline Ribosomal proteins & $15,1 \%$ & 184 & Ribosomal proteins & $14,5 \%$ & 174 \\
\hline Growth factors & $0,3 \%$ & 4 & Growth factors & $0,2 \%$ & 3 \\
\hline Beta-lactoglobulin & $2,2 \%$ & 27 & Beta-lactoglobulin & $1,9 \%$ & 23 \\
\hline Lactalbumin & 0 & 0 & Lactalbumin & $0,6 \%$ & 8 \\
\hline Beta-2-microglobulin & $0,4 \%$ & 5 & Beta-2-microglobulin & $0,4 \%$ & 6 \\
\hline $\begin{array}{l}\text { Fatty acid synthase } \\
\text { (FASN) }\end{array}$ & $0,5 \%$ & 7 & $\begin{array}{c}\text { Fatty acid synthase } \\
\text { (FASN) }\end{array}$ & $0,08 \%$ & 1 \\
\hline $\begin{array}{l}\text { Fatty acid binding } \\
\text { protein }\end{array}$ & 0 & 0 & $\begin{array}{l}\text { Fatty acid binding } \\
\text { protein }\end{array}$ & $0,3 \%$ & 4 \\
\hline
\end{tabular}

\section{References}

[1] TurkStat, Animal Production Statistics, 2016, http://www.tuik .gov.tr/.

[2] General Directorate of Agricultural Research and Policie, Türkiye Evcil Hayvan Genetik Kaynakları Tanıtım Kataloğu, General Directorate of Agricultural Research and Policie, Ankara, Turkey, 2009.

[3] R. Pakkanen and J. Aalto, "Growth factors and antimicrobial factors of bovine colostrum," International Dairy Journal, vol. 7, no. 5, pp. 285-297, 1997.

[4] F. O. Uruakpa, M. A. H. Ismond, and E. N. T. Akobundu, "Colostrum and its benefits: a review," Nutrition Research, vol. 22 , no. 6 , pp. 755-767, 2002.

[5] S. E. Pattinson and E. W. Thomas, "The effect of sire breed on colostrum production of crossbred ewes," Livestock Production Science, vol. 86, no. 1-3, pp. 47-53, 2004.

[6] A. Argüello, N. Castro, M. J. Zamorano, A. Castroalonso, and J. Capote, "Passive transfer of immunity in kid goats fed refrigerated and frozen goat colostrum and commercial sheep colostrum," Small Ruminant Research, vol. 54, no. 3, pp. 237-241, 2004.

[7] J. C. Chen, C. J. Chang, H. C. Peh, and S. Y. Chen, "Serum protein levels and neonatal growth rate of Nubian goat kids in Taiwan area," Small Ruminant Research, vol. 32, no. 2, pp. 153160, 1999.

[8] S. Kráčmar, J. Kuchtík, M. Baran et al., "Dynamics of changes in contents of organic and inorganic substances in sheep colostrum within the first $72 \mathrm{~h}$ after parturition," Small Ruminant Research, vol. 56, no. 1-3, pp. 183-188, 2005.

[9] H. S. Umberger, "Profitable artificial rearing of lambs," Animal and Poultry Sciences Publication No. 410-023, Virginia Cooperative Extension, 1997.
[10] S.-Y. Ying, "Complementary DNA libraries: an overview," Applied Biochemistry and Biotechnology-Part B Molecular Biotechnology, vol. 27, no. 3, pp. 245-252, 2004.

[11] M. D. Adams, J. M. Kelley, J. D. Gocayne et al., “Complementary DNA sequencing: expressed sequence tags and human genome project," Science, vol. 252, no. 5013, pp. 1651-1656, 1991.

[12] L.-X. Du, S.-F. Liu, J. Zhu et al., "Construction of SMART cDNA library of sheep ovary and identification of candidate gene by homologous cloning," Agricultural Sciences in China, vol. 6, no. 11, pp. 1390-1395, 2007.

[13] J. Sambrook, E. F. Fritsch, and T. Maniatis, Moleculer Clonning: A Laboratory Manuel, vol. 2nd, Cold Spring Harbor Laboratory, Cold Spring Harbor, NY, USA, 1989.

[14] B. Ewing, L. Hillier, M. C. Wendl, and P. Green, "Base-calling of automated sequencer traces using phred. I. accuracy assessment," Genome Research, vol. 8, no. 3, pp. 175-185, 1998.

[15] B. Ewing and P. Green, "Base-calling of automated sequencer traces using phred. II. Error probabilities," Genome Research, vol. 8, no. 3, pp. 186-194, 1998.

[16] X. Huang and A. Madan, "CAP3: a DNA sequence assembly program," Genome Research, vol. 9, pp. 868-877, 1999.

[17] X. Huang, "An improved sequence assembly program," Genomics, vol. 33, no. 1, pp. 21-31, 1996.

[18] J. E. Koltes, Z.-L. Hu, E. Fritz, and J. M. Reecy, "BEAP: the BLAST extension and alignment program-a tool for contig construction and analysis of preliminary genome sequence," BMC Research Notes, vol. 2, article 11, 2009.

[19] S. F. Altschul, W. Gish, W. Miller, E. W. Meyers, and D. J. Lipman, "Basic local alignment search tool," Journal of Molecular Biology, vol. 215, no. 3, pp. 403-410, 1990.

[20] M. Kearse, R. Moir, A. Wilson et al., "Geneious basic: an integrated and extendable desktop software platform for the organization and analysis of sequence data," Bioinformatics, vol. 28, no. 12, pp. 1647-1649, 2012. 
[21] P. D. Thomas, M. J. Campbell, A. Kejariwal et al., "PANTHER: a library of protein families and subfamilies indexed by function," Genome Research, vol. 13, no. 9, pp. 2129-2141, 2003.

[22] S. Chen, H. Miao, F. Chen, B. Jiang, J. Lu, and W. Fang, "Analysis of expressed sequence tags (ESTs) collected from the inflorescence of chrysanthemum," Plant Molecular Biology Reporter, vol. 27, no. 4, pp. 503-510, 2009.

[23] W.-K. Wang, C.-C. Liu, T.-Y. Chiang, M.-T. Chen, C.-H. Chou, and C.-H. Yeh, "Characterization of expressed sequence tags from flower buds of alpine Lilium formosanum using a subtractive cDNA library," Plant Molecular Biology Reporter, vol. 29, no. 1, pp. 88-97, 2011.

[24] D. Yang, Z. H. Tang, L. P. Zhang, C. P. Zhao, and Y. L. Zheng, "Construction, characterization, and expressed sequence tag (EST) analysis of normalized cDNA library of thermo-photoperiod-sensitive genic male sterile (TPGMS) wheat from spike developmental stages," Plant Molecular Biology Reporter, vol. 27, no. 2, pp. 117-125, 2009.

[25] Y. Gueguen, J.-P. Cadoret, D. Flament et al., "Immune gene discovery by expressed sequence tags generated from hemocytes of the bacteria-challenged oyster, Crassostreagigas," Gene, vol. 303, pp. 139-145, 2003.

[26] T. Thanh, V. T. Q. Chi, M. P. Abdullah et al., "Construction of cDNA library and preliminary analysis of expressed sequence tags from green microalga Ankistrodesmus convolutus Corda," Molecular Biology Reports, vol. 38, no. 1, pp. 177-182, 2011.

[27] Z. Su, X. Dong, B. Zhang et al., "Gene expression profiling in porcine mammary gland during lactation and identification of breed-and developmental-stage-specific genes," Science in China Series C, vol. 49, no. 1, pp. 26-36, 2006.

[28] Y. Gao, X. Lin, K. Shi, Z. Yan, and Z. Wang, "Bovine mammary gene expression profiling during the onset of lactation," PLOS ONE, vol. 8, no. 8, Article ID e70393, 2013.

[29] G. W. Robinson, R. A. McKnight, G. H. Smith, and L. Hennighausen, "Mammary epithelial cells undergo secretory differentiation in cycling virgins but require pregnancy for the establishment of terminal differentiation," Development, vol. 121, no. 7, pp. 2079-2090, 1995. 

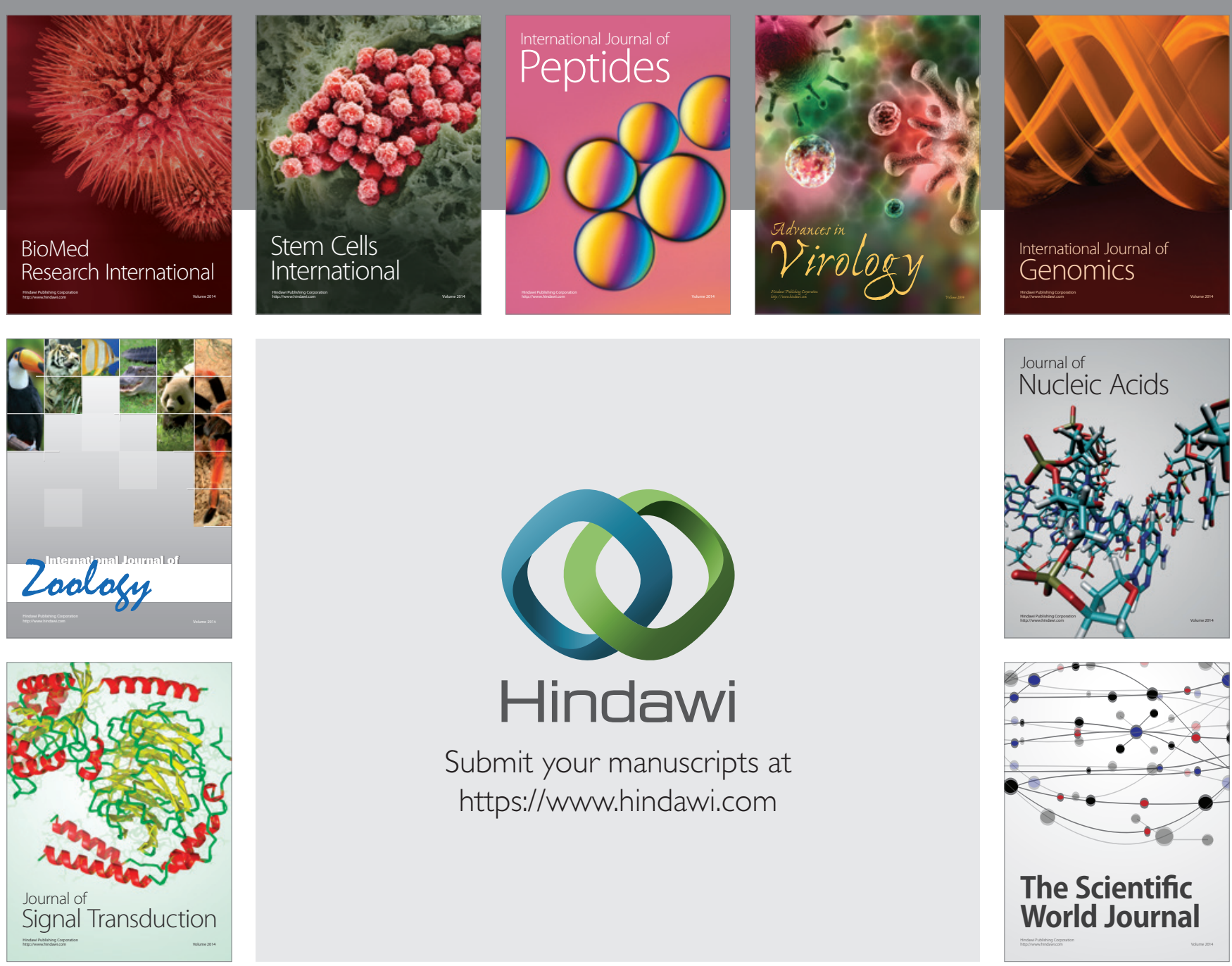

Submit your manuscripts at

https://www.hindawi.com
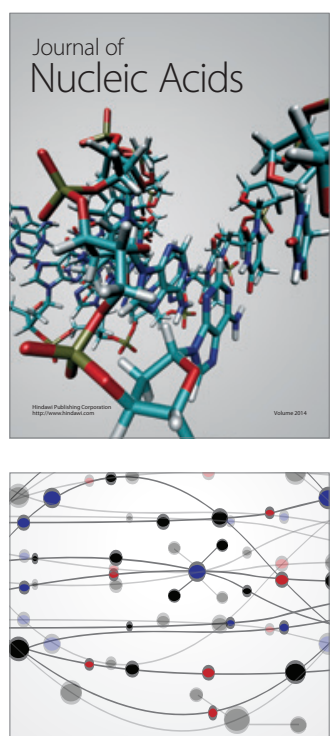

The Scientific World Journal
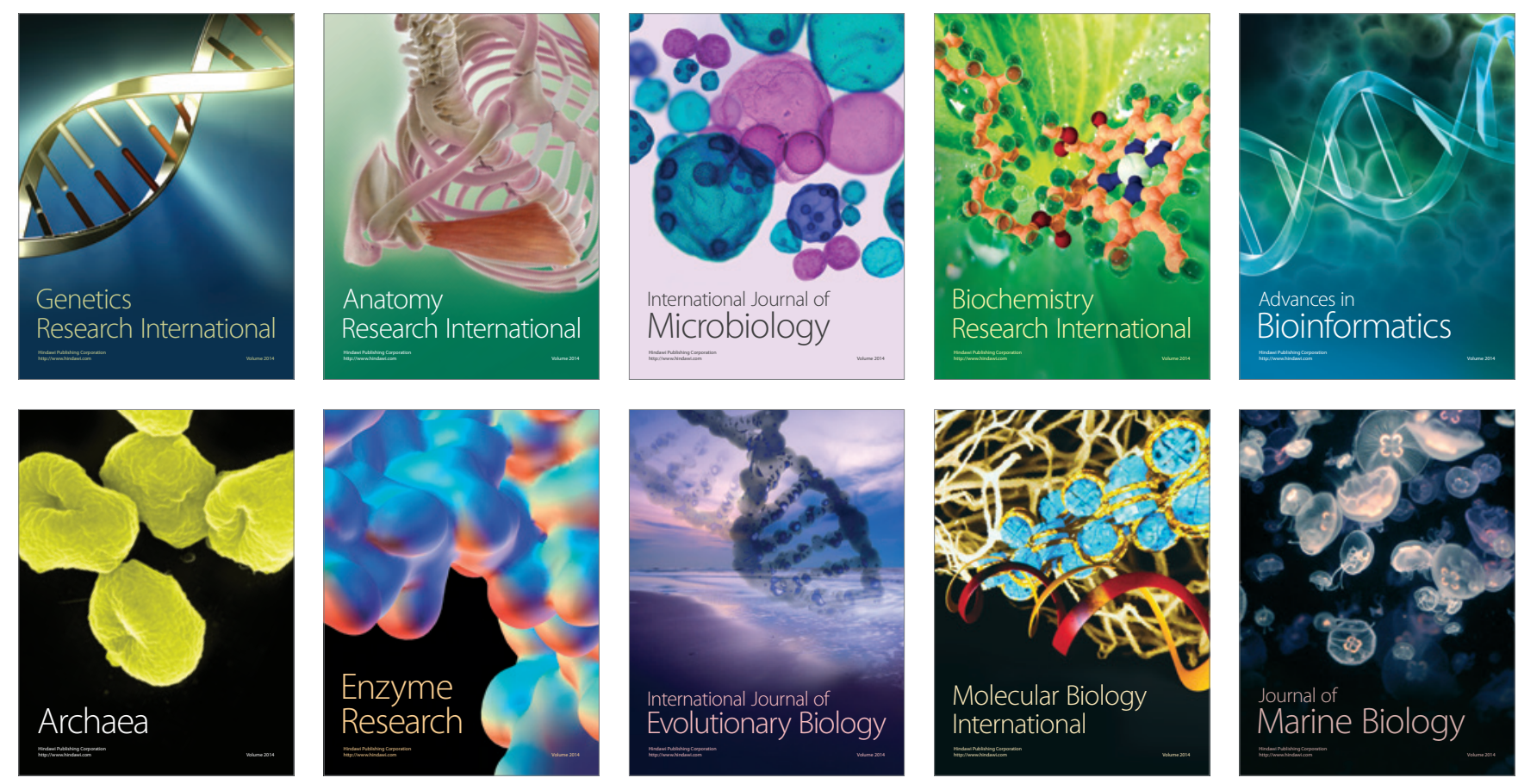